\title{
ARTIKELEN
}

\section{De ruimtegevende wetgever}

\section{Het right to challenge in vergelijking tot andere ruimtegevende instrumenten ${ }^{*}$}

D.R.P. de Kok

\section{Inleiding}

In het jaarverslag over 2018 heeft de Raad van State 'de waarde van de wet en van het wetgevingsproces' als centraal onderwerp gekozen. De Raad merkt op dat de wet

'een pijler [moet] zijn van "buigzaam beton". Een goede wet balanceert tussen zekerheid en flexibiliteit. Zekerheid om maatschappelijke verhoudingen te ondersteunen, noodzakelijke gelijkheid te waarborgen en de macht van de overheid te begrenzen. Flexibiliteit om nieuwe maatschappelijke opgaven het hoofd te bieden en om vooruit te komen.' ${ }^{1}$

Twee waarden dus, zekerheid en flexibiliteit, waartussen een balans moet worden gevonden. Wat opvalt is dat in het vervolg van het jaarverslag de waarde van de zekerheid de duidelijke winnaar is. Het bovenstaande citaat is niet voor niets opgenomen in een paragraaf met het kopje 'Houvast in wet', dat wordt gevolgd door de paragraaf 'Houvast aan wetgevingsprocedure'. De flexibiliteit komt er verder bekaaid af. In paragraaf 1.3 ('Andere procedures en vormen van overheidsregulering') geeft de Raad vooral voorbeelden van hoe die flexibiliteit volgens hem niet moet worden bereikt. Op de keuzes van de regering voor het sluiten van akkoorden (p. 17-19), 'wetgeving op verzoek' (p. 19-20), het hanteren van open normen en ruime delegatiemogelijkheden (p. 20-23), kaderwetgeving (p. 23-24) en experimenteerwetgeving (p. 24-25) heeft de Raad voornamelijk kritiek. Waarschijnlijk komt deze nadruk op het belang van rechtszekerheid vooral voort uit een opvatting dat de regering te vaak het belang van de flexibiliteit vooropstelt. De eigen adviezen op concrete voorstellen die de Raad bij de bespreking van de genoemde onderwerpen aanhaalt, duiden daarop. De Raad denkt dus waarschijnlijk de balans tussen flexibiliteit en zekerheid te kunnen vinden door 'tegen te gaan hangen' aan de kant van de zekerheid.

Het feit dat de Raad niet aangeeft hoe die flexibiliteit dan wel kan worden bereikt, heeft naar mijn mening iets onbevredigends. Daarom doe ik in dit artikel een

* De auteur schrijft dit artikel op persoonlijke titel.

1 Jaarverslag Raad van State 2018, p. 11. 
poging om die vraag wel te beantwoorden. Daarbij concentreer ik me op een bespreking van 'ruimtegevende' instrumenten: ${ }^{2}$ instrumenten die ruimte bieden voor maatschappelijke ontwikkelingen en daarmee de benodigde flexibiliteit geven, waaronder het right to challenge. ${ }^{3}$ Eerst ga ik in paragraaf 2 in op het (toenemende) belang van flexibiliteit in wetgeving en op de ontwikkeling van het right to challenge in dat verband. In paragraaf 4 categoriseer ik de verschillende instrumenten op basis van indelingscriteria die ik in paragraaf 3 bespreek, en zet ze af tegen het right to challenge, dat in dit themanummer centraal staat. Sommige instrumenten voorzie ik van een kritische beschouwing. Ik eindig in paragraaf 5 met een conclusie en aanbevelingen, onder andere tot aanpassing van de Aanwijzingen voor de regelgeving (Ar).

\section{Het belang van flexibiliteit, en het right to challenge in dat verband}

Blijkens het regeerakkoord is een voornemen van het kabinet-Rutte III ruimte te bieden aan ondernemers, onder meer door wet- en regelgeving te moderniseren 'zodat bedrijven met hun diensten en producten beter kunnen inspelen op maatschappelijke en technologische veranderingen'. ${ }^{4}$ Ter uitvoering van dit voornemen heeft het kabinet op 15 juni 2018 de Programmabrief 'Merkbaar betere regelgeving en dienstverlening 2018-2021' aan de Tweede Kamer gestuurd, waarin onder andere de volgende passage is opgenomen:

'Zoals in het regeerakkoord staat, is het werken aan moderne en innovatievriendelijke wet- en regelgeving een belangrijke ambitie van het kabinet. Steeds sneller veranderende maatschappelijke en technologische ontwikkelingen vragen om een overheid die in staat is heldere (spel)regels te formuleren en tegelijkertijd wendbaar en flexibel genoeg is om ondernemers de ruimte te bieden om op deze ontwikkelingen en kansen in te spelen. Het betere regelgevingsbeleid gaat precies om dit uitdagende spanningsveld: het tot stand brengen van wet- en regelgeving die publieke belangen borgen, zonder dat dit tot onnodige kosten en belemmeringen leidt voor ondernemerschap en innovatie. Hoe beter we in staat zijn deze balans te vinden, des te gunstiger het ondernemersklimaat. ${ }^{5}$

Dezelfde balans dus als waar de Raad van State het in zijn jaarverslag 2018 over heeft, maar met een geheel andere focus. Met deze passage gaat het kabinet-Rutte

2 Zie over ruimtegevende instrumenten in algemene zin: F.J. van Ommeren, 'Wetgevingsbeleid: remedies en instrumenten', in: S.E. Zijlstra (red.), Wetgeven. Handboek voor de centrale en decentrale overheid, Deventer: Kluwer 2012, p. 176 e.v.

3 Daarbij doel ik dus op het right to challenge als wetgevingsinstrument. Zie over het gebruik van het right to challenge als bestuursinstrument, in de zin van een instrument dat het mogelijk maakt voor maatschappelijke partijen om het beleid van een (decentraal) bestuursorgaan mede te bepalen, de artikelen van Driessen, Boogaard en Den Ouden en van Kwast in dit themanummer.

4 Regeerakkoord 'Vertrouwen in de toekomst' van het kabinet-Rutte III, p. 33.

$5 \quad$ Kamerstukken II 2017/18, 32637, nr. 314, p. 1. 
III voort op de lijn die onder het kabinet-Rutte II is ingezet. In het programma Toekomstbestendige wetgeving van dat kabinet kwam het belang van flexibiliteit ook al prominent aan de orde:

'Om in te spelen op de toenemende dynamiek en complexiteit van de netwerksamenleving zal de overheid er voor moeten zorgen dat wetgeving toekomstbestendig is en waar mogelijk ruimte biedt voor innovatie en initiatieven uit de samenleving. ${ }^{6}$

Een van de speerpunten van dit programma was de uitwerking van het right to challenge als ruimtegevend wetgevingsinstrument. ${ }^{7}$ In die vorm is het right to challenge, ook wel 'uitdaagrecht', kortweg aan te duiden als het recht voor maatschappelijke partijen (burgers, bedrijven, instellingen) om de overheid te verzoeken (uit te dagen) om ruimte om op een andere wijze het doel van regelgeving te bereiken dan door het volgen van de daartoe opgestelde regels. In paragraaf 4.3.1 ga ik nader in op de juridische inbedding. Het right to challenge in deze vorm is nader uitgewerkt in een 'factsheet' en een handreiking in de 'index beleidsinstrumenten' in het Integraal afwegingskader voor beleid en regelgeving (IAK). ${ }^{8}$

De toch al volle index beleidsinstrumenten is met de komst van het right to challenge dus verder uitgebreid. Deze instrumenten worden in het IAK naast elkaar gepresenteerd, zonder een indicatie welk instrument nu precies voor welk probleem het best kan worden ingezet. In de Ar, waarin ook een aantal instrumenten wordt besproken, wordt slechts sporadisch iets gezegd over de wenselijkheid van de toepassing daarvan en ontbreekt een samenhang daarin. Ik probeer met deze bijdrage in die lacune te voorzien.

\section{Indelingscriteria}

Alvorens ik tot een bespreking van de verschillende ruimtegevende instrumenten overga, wil ik eerst de lijnen schetsen waarlangs de instrumenten kunnen worden ingedeeld. Ik zie er twee.

\subsection{Regelgevende bevoegdheid of bestuursbevoegdheid?}

Een belangrijk onderscheid is dat tussen regelgevende bevoegdheden en bestuursbevoegdheden. Is het de (gedelegeerde) regelgever die met algemeen verbindende voorschriften de flexibiliteit moet bieden, of het bestuursorgaan met zijn (door de wetgever gegeven) besluitvormende bestuursbevoegdheden? In de praktijk wordt

$6 \quad$ Kamerstukken II 2015/16, 33009, nr. 30, p. 1.

7 Zie de diverse brieven aan de Tweede Kamer over het programma Toekomstbestendige wetgeving, onder Kamerstuknummer 33009, nrs. 10, 12, 30 en 42. Met name onder nr. 10, p. 8, en nr. 30, p. 4-7, wordt uitgebreid ingegaan op het right to challenge.

8 Zie www.kcwj.nl/kennisbank/integraal-afwegingskader-voor-beleid-en-regelgeving/index-beleids instrumenten/right-challenge. 
dit onderscheid soms niet helder gemaakt. Toch is dit onderscheid van groot belang vanwege de vraag of er bezwaar en beroep openstaat tegen het al dan niet maken van een uitzondering. Op grond van artikel 8:3, eerste lid, aanhef en onderdeel a, van de Algemene wet bestuursrecht (Awb) kan immers geen beroep worden ingesteld (en krachtens art. 7:1 Awb dus ook geen bezwaar worden gemaakt) tegen een besluit inhoudende een algemeen verbindend voorschrift.

\subsection{Algemeen of bijzonder?}

Een tweede indelingscriterium is dat tussen instrumenten die in het algemeen flexibiliteit bieden en instrumenten die bijzondere regimes mogelijk maken. Dit onderscheid komt bij zowel wetgevingsinstrumenten ${ }^{9}$ als bestuursinstrumenten voor:

- Bij wetgevingsinstrumenten gaat het om het verschil tussen het zodanig vormgeven van de norm zelf dat deze ruimte laat voor meerdere invullingen, en het bieden van een (delegatie)mogelijkheid om andere, zo nodig afwijkende, regels te stellen voor bijzondere gevallen. In het eerste geval zorgt de norm in het algemeen voor de benodigde flexibiliteit, in het tweede geval kan de gedelegeerde regelgever in bijzondere gevallen kiezen voor een bijzondere regeling waarmee hij de benodigde flexibiliteit biedt.

- Bij bestuursinstrumenten gaat het om het verschil tussen instrumenten die bedoeld zijn om eenieder die onder de gemaakte uitzondering valt of zich daaronder schaart van die uitzondering gebruik te laten maken, en instrumenten die bedoeld zijn om individuele uitzonderingen mogelijk te maken en daarbij daadwerkelijk maatwerk te bieden.

\section{De ruimtegevende instrumenten}

Hieronder ga ik nader in op de verschillende ruimtegevende instrumenten. Ik hanteer daarbij de twee indelingscriteria die ik in paragraaf 3 heb behandeld. Ik pretendeer daarbij niet een uitputtend overzicht te bieden van al deze instrumenten, wel van de belangrijkste. Telkens zet ik de instrumenten af tegen het right to challenge, dat ik in paragraaf 4.3.1 nader bespreek.

\subsection{Algemene wetgevingsinstrumenten}

\subsubsection{Open normen}

Een eerste mogelijkheid om wetgeving flexibel te maken is die wetgeving zo te formuleren dat er meerdere mogelijkheden zijn om eraan te voldoen. In de eerste plaats valt dan te denken aan het gebruik van open normen. Deze kunnen variëren van zorgplichten waarin niet meer is vastgelegd dan de verplichting om zorg te betrachten voor een bepaald publiek belang, tot doelvoorschriften waarin

9 In dit artikel gebruik ik de term wetgevingsinstrument in brede zin als een manier om te sturen door middel van het stellen van algemeen verbindende voorschriften, voor zowel de formele wetgever als de decentrale regelgever. Om een wetgevingsinstrument te kunnen inzetten is dus een regelgevende bevoegdheid nodig. 
bijvoorbeeld is vastgelegd welk geluidsniveau een discotheek mag produceren, zonder vast te leggen welke maatregelen daarvoor moeten worden genomen. Het grote voordeel van dit soort normen is dat er geen bijzondere regelgeving hoeft te worden gecreëerd, wat uiteraard zowel administratieve lasten (voor burgers, bedrijven, instellingen) als bestuurlijke lasten scheelt. Het grote nadeel is dat de norm minder houvast biedt, waardoor er toch vaak behoefte is aan nadere invulling van de wetgever ... en er daarmee toch bijzondere regelgeving komt, maar dan bijvoorbeeld in de vorm van nadere instructies van toezichthouders die minder goed kenbaar zijn. En een nadeel is natuurlijk ook dat er een grotere kans op juridificering is door de interpretatieruimte die er wordt gelaten. ${ }^{10}$ Over open normen valt natuurlijk veel meer te zeggen, en dat is ook gedaan in zeer veel artikelen en boeken. ${ }^{11}$ Maar in dit artikel, dat beoogt een algemeen overzicht te bieden van de verschillende instrumenten, laat ik het hierbij.

Indien dergelijke open normen sec worden gebruikt, is de inzet van een right to challenge niet aan de orde. Het right to challenge wordt immers pas interessant indien er middelvoorschriften zijn die belemmerend kunnen werken voor andersoortige manieren om de doelen van de regelgeving te bereiken. Indien wordt volstaan met open normering zijn er geen middelvoorschriften, maar is juist het doel zelf de norm, waarbij alle manieren om dat doel te bereiken zijn geoorloofd. Een open norm komt echter ook voor mét middelvoorschriften. Deze middelvoorschriften kunnen dan het karakter hebben van facultatieve bepalingen: 'aan [het doelvoorschrift] is in ieder geval voldaan indien ...' Ook in dat geval is geen right to challenge nodig, omdat de voorschriften facultatief zijn. Indien de middelvoorschriften wél een verplichtend karakter hebben, krijgt het doelvoorschrift het karakter van een ijkpunt voor het right to challenge. ${ }^{12}$

\subsubsection{Techniekneutrale normen}

Een mogelijkheid in dezelfde sfeer is het techniekneutraal formuleren van normen. De regelgeving richt zich dan op functionele beginselen en normen en schrijft niet voor welke techniek daarbij wordt gebruikt. Uiteraard beperkt deze mogelijkheid zich tot situaties waarin naleving van normen het hanteren van technieken vergt. Maar dat kan zich eerder voordoen dan wellicht gedacht. Zo is in de memorie van toelichting bij de Wet elektronisch bestuurlijk verkeer (de invoering van afdeling 2.3 Awb) een mooie 'techniekneutrale interpretatie' avant la lettre gegeven van het begrip 'schriftelijk':

'Het begrip "schriftelijk" kan op meerdere manieren worden uitgelegd. Van oudsher beoogt het tot uitdrukking te brengen dat de betrokken handeling op papier dient te staan in de vorm van schrifttekens. (...) Het begrip "schriftelijk" kan echter ook worden opgevat als: weergave door middel van schrifttekens. In die betekenis is irrelevant wat de drager van de schrifttekens is. Dat

10 In die zin ook: Jaarverslag Raad van State 2018, p. 22.

11 In kritische zin bijv. P. Westerman, Outsourcing the Law. A Philosophical Perspective on Regulation, Cheltenham/Northampton: Edward Elgar Publishing 2018.

12 Meer hierover in de bijdrage van In 't Hout elders in dit nummer. 
kan papier zijn, maar ook een diskette, een harde schijf of een andere informatiedrager. ${ }^{13}$

Laatstgenoemde interpretatie is gekozen. Dat heeft ervoor gezorgd dat bepalingen waarin de term 'schriftelijk' voorkomt automatisch van toepassing zijn op nieuwe soorten informatiedragers. Ook communicatie via apps op de smartphone, die bij de indiening van het wetsvoorstel in 2002 nog niet in beeld was, is onder de term gaan vallen zonder dat de wet daarvoor moest worden aangepast. De wet stond dus ook niet aan die ontwikkeling in de weg.

Ten opzichte van het right to challenge kan hier hetzelfde worden gezegd als bij open normen: door geen techniek voor te schrijven worden nieuwe technieken niet belemmerd, en is er dus ook geen reden om een right to challenge in te voeren.

\subsubsection{Beste beschikbare technieken}

Door voor te schrijven dat voor het naleven van bepaalde normen de beste beschikbare technieken ${ }^{14}$ worden gehanteerd, worden technologische innovaties automatisch meegenomen in de regelgeving. Deze optie is te zien als een kruising tussen een open norm en een techniekneutrale norm. De norm schuift mee omhoog met de technologische innovaties: komt er een nieuwe, betere techniek beschikbaar, dan wordt die de nieuwe norm. Voorbeelden van het gebruik van deze optie komen we met name tegen in het milieurecht. ${ }^{15}$

We zouden het voorschrijven van het gebruik van de beste beschikbare techniek kunnen beschouwen als een 'geïnstitutionaliseerd' right to challenge. De technische innovatie wordt hier immers niet alleen mogelijk gemaakt, zoals bij open en techniekneutrale normen, maar zelfs tot norm verheven. Daarmee verlegt de innovator die norm voor zichzelf en voor anderen.

\subsection{Bijzondere wetgevingsinstrumenten}

\subsubsection{Experimenteerbepalingen}

In de toelichting bij Ar 2.41 wordt een experiment omschreven als 'het proefondervindelijk vaststellen of een bepaald instrument een bijdrage levert aan het oplossen van een maatschappelijk probleem'. Dat dit 'instrument' een regeling is, maakt de tekst van de aanwijzing zelf duidelijk: het gaat om een lagere regeling waarmee bij wijze van experiment van een hogere regeling wordt afgeweken.

13 Kamerstukken II 2001/02, 28483, nr. 3, p. 6.

14 In de regelgeving komt deze term ook wel voor zonder 'e' aan het eind van het eerste woord, wat tot de waarschijnlijk onbedoelde interpretatie kan leiden dat niet de beste techniek die beschikbaar is moet worden gebruikt, maar de techniek die het best beschikbaar is.

15 Bijv. art. 2.14, eerste lid, onderdeel c, onder $1^{\circ}$, Wet algemene bepalingen omgevingsrecht, art. 4.22, tweede lid, onderdeel c, van diens opvolger, de Omgevingswet, en art. 3, derde lid, Wet ammoniak en veehouderij. 
Vervolgens vermeldt de aanwijzing dat deze lagere regeling in principe op het niveau van een algemene maatregel van bestuur moet worden getroffen.

In de Kamerbrief naar aanleiding van de voornemens in het huidige regeerakkoord over het vergroten van de wettelijke experimenteerruimte wordt echter een veel breder begrip 'experimenteren' gebruikt. Er staat onder andere het volgende:

'Vaak blijkt dat de bestaande wet- en regelgeving meer ruimte biedt dan men denkt, zodat experimenteren zonder aanpassing van wet- en regelgeving mogelijk is. Deze ruimte kan te vinden zijn door een verandering in interpretatie, in de wijze van uitvoering of het toezicht, maar ook door bestaande afwijkingsmogelijkheden in wetgeving te benutten zoals experimenteerbepalingen of ontheffings- en vrijstellingsmogelijkheden.' ${ }^{\text {16 }}$

Experimenteren kan dus ook door een vrijstelling of ontheffing te verlenen. Daarmee sluit de regering aan bij de praktijk. Er bestaan namelijk al verschillende experimenteerbepalingen waarin niet Ar 2.41 is gevolgd, maar gekozen is voor het regelen van een experiment bij vrijstelling of ontheffing. Een voorbeeld van het laatste is artikel 7a van de Elektriciteitswet 1998, zoals dat komt te luiden na inwerkingtreding van de Wet van 9 april 2018 tot wijziging van de Elektriciteitswet 1998 en van de Gaswet (voortgang energietransitie) (Stb. 2018, 109). ${ }^{17} \mathrm{Ik}$ noem dit voorbeeld met name omdat er met die wijzigingswet voor is gekozen om over te stappen van de 'klassieke' experimenteerbepaling overeenkomstig Ar 2.41 (waarbij dus bij algemene maatregel van bestuur bij wege van experiment kan worden afgeweken van het bepaalde bij of krachtens de wet) naar een bepaling waarin de Minister van Economische Zaken en Klimaat de bevoegdheid krijgt om bij wege van experiment een ontheffing te verlenen. Deze wijziging is zonder noemenswaardige slag of stoot tot wet verheven. De Raad van State maakte er in zijn advies $^{18}$ geen woorden aan vuil. In de Kamerbehandeling kwam de experimenteermogelijkheid weliswaar aan de orde, maar daarbij ging het niet over de genoemde overstap van algemene maatregel van bestuur naar ontheffing. Dit wordt wellicht verklaard door het feit dat de huidige algemene maatregel van bestuur (het Besluit experimenten decentrale duurzame elektriciteitsopwekking) op grond van het huidige artikel 7a de mogelijkheid om een experiment te starten al 'doordelegeert' naar een ontheffing van de minister. In zoverre wordt nu al niet 34775 VI, nr. 114, p. 2.

17 Zie voor meer voorbeelden van ontheffings- of zelfs vergunningsmogelijkheden voor het houden van een experiment: E.S. Cnossen \& L.L. van der Laan, 'Structurele experimenteergrondslagen: een blik op de wetgevingspraktijk', in: S.S. Zoeteman (red.), Experimenteerwetgeving (Nederlandse Vereniging voor Wetgevingsbeleid), Tilburg: Wolf Legal Publishers 2018, p. 79-95, en M.J. Jacobs, Experimentele wetgeving, Deventer: Wolters Kluwer 2018, par. 3.2.2.

18 Advies van 30 september 2016, nr. W15.16.0181/IV; zie ook Kamerstukken II 2016/17, 34627, nr. 4. 
voldaan aan Ar 2.41 en is de wetswijziging dus bedoeld om de wettelijke grondslag in lijn te brengen met de ontstane praktijk. ${ }^{19}$

Dat voor de weg van een ontheffings-, vrijstellings- of vergunningsbevoegdheid wordt gekozen, is wellicht niet verwonderlijk, gezien de strenge eisen die Ar 2.41 stelt. In de experimenteerbepaling in een wet moet worden bepaald:

a wat het oogmerk is van het experiment;

b wat het bereik is van de experimenteerregeling;

c van welke onderdelen van de hogere regeling kan worden afgeweken; en

d wat de maximale geldingsduur is van de afwijking.

In zijn advies over de Experimentenwet rechtspleging ${ }^{20}$ heeft de Raad van State nog een aantal eisen genoemd, die weliswaar specifiek voor experimenten op grond van die wet zouden moeten gelden, maar waarschijnlijk deels algemeen bedoeld zijn:

- Er moet een duidelijke afbakening zijn van waar het experiment over kan gaan en wat de reikwijdte van het experiment is, ook in territoir.

- Er moeten duidelijke criteria worden gesteld voor de opzet en de evaluatie van een experiment.

- Er moet een duidelijk, wetenschappelijk verantwoord onderzoek worden gedaan naar de resultaten van een evaluatie door een deskundige en onafhankelijke instantie.

- De beschrijving van een voornemen tot een experiment zal onder andere in moeten gaan op de aard van het probleem, een overzicht moeten bevatten van al bestaand onderzoek in relatie tot de relevante beleidstheorie, de met het experiment beoogde doelen, de afbakening van de wettelijke regeling en een motivering van de wijze waarop er wordt geëvalueerd.

- De toetsing of voldaan is aan de eisen voor zo'n experiment zou kunnen worden opgedragen aan een onafhankelijke adviescommissie. Het is niet duidelijk of de Raad vindt dat dit ook voor andersoortige, kleinere experimenten geldt.

Ar 5.17 geeft geen richtlijnen (en dus ook geen restricties) voor de inzet van de vrijstelling, ontheffing en vergunning. Dit maakt het opnemen van deze instrumenten wellicht aantrekkelijk.

Maar de gedachte bij experimenteren is dat het de regelgever is die andersoortige regelgeving uitprobeert om op basis van de ervaringen te besluiten over wijziging van de wet, zoals Ar 2.41 veronderstelt. Vrijstellings-, ontheffings- en vergunningsmogelijkheden zijn bedoeld voor een bestuursorgaan om bepaalde maatschappelijke partijen (burgers, bedrijven, instellingen) op aanvraag uit te zonderen van de regels. Daarmee zij die instrumenten wel geschikt voor het geven van ruimte

19 Dit verklaart dan op zijn beurt waarschijnlijk de wat wonderlijke zin in de memorie van toelichting dat met de wijziging 'de mogelijkheid [wordt] verruimd om bij algemene maatregel van bestuur bij wijze van experiment af te wijken van het bepaalde bij of krachtens die wet' (Kamerstukken II 2016/17, 34627, nr. 3, p. 25).

20 Advies van 27 februari 2019, nr. W16.18.0315/II; zie ook Kamerstukken II 2018/19, 35263, nr. 4. 
aan maatschappelijke partijen voor maatschappelijke initiatieven of ontwikkelingen (waarmee we op het terrein van het right to challenge komen), maar niet voor experimenten met regelgeving. Daarom wijs ik het gebruik van die instrumenten voor het uitvoeren van experimenten af en heb ik het instrument in deze paragraaf opgenomen.

\subsubsection{Decentralisatie}

Een andere manier (het is wellicht wat te vergaand om hier over een 'instrument' te spreken) om door middel van specifieke regelgeving in te kunnen spelen op maatschappelijke ontwikkelingen is het decentraliseren van die regelgeving. Als er landelijk niet één regime kan gelden voor het reguleren van bepaalde onderwerpen omdat er regionaal of lokaal gerechtvaardigde verschillen zijn, is het zinvol na te denken over mogelijkheden om de regulering aan decentrale overheden over te laten. Dat kan via een medebewindsopdracht of door als landelijke wetgever juist een stap terug te doen en regulering over te laten aan de autonome ruimte van decentrale overheden. Op de terreinen van de zorg en het natuurbeleid zijn redelijk recent dergelijke decentralisatieoperaties uitgevoerd.

In relatie tot het right to challenge is het interessant om te wijzen op het wetsvoorstel voor de Experimentenwet gemeenten. Dit wetsvoorstel beoogde (in hoofdstuk 1) burgemeester en wethouders de mogelijkheid te geven een voorstel bij de Minister van Binnenlandse Zaken en Koninkrijksrelaties (BZK) in te dienen voor een door die gemeente uit te voeren experiment, dat zou nopen tot afwijking van hogere regels. De Minister van BZK zou vervolgens, samen met de minister op wiens beleidsterrein het voorstel betrekking had, een wetsvoorstel kunnen indienen om voor die gemeente(n) de gevraagde ruimte te bieden in hoofdstuk 2 van diezelfde wet. Het wetsvoorstel kon dus worden gezien als een mix van experimenteerwetgeving (gezien de naam; zie mijn beschouwing in par. 4.2.1), decentralisatie (want het doel was gemeenten ruimte te bieden voor lokaal maatwerk en innovatie ${ }^{21}$ ) en het right to challenge (omdat gemeenten de mogelijkheid kregen de landelijke wetgeving 'uit te dagen' indien zij van mening waren dat zij zelf beter in staat waren bepaalde publieke belangen te dienen). Het wetsvoorstel was overigens geen gelukkig lot beschoren: de Raad van State had bezwaar tegen zowel de vorm als de inhoud van het wetsvoorstel en adviseerde het niet in te dienen (het meest negatieve advies, het toenmalige dictum 6). De voornaamste kritiek van de Raad was, kort gezegd, dat het wetsvoorstel leidde tot juridisering van een proces tot het wegnemen van knelpunten voor gemeenten, dat ook zonder wet kon worden gevoerd. De regering besloot het advies te volgen. ${ }^{22}$

21 Zie ook de brief van de Minister van Binnenlandse Zaken en Koninkrijksrelaties aan de Tweede Kamer van 19 februari 2018, waarin werd meegedeeld dat het wetsvoorstel niet zou worden ingediend, Kamerstukken II 2017/18, 34775 VII, nr. 53, p. 3.

22 Advies W04.16.0316/I van 25 januari 2017 en nader rapport van 22 februari 2018, Stcrt. 2018, 10862. 


\subsection{Algemene bestuursinstrumenten}

\subsubsection{Right to challenge}

In paragraaf 2 ben ik al ingegaan op de achtergronden; in deze paragraaf wil ik ingaan op de juridische kwalificatie en inbedding. Het right to challenge is geen nieuw instrument. Met name in de bouwregelgeving bestaat het al langer. In een andere bijdrage aan dit themanummer van RegelMaat gaat In 't Hout hier nader op in. In juridische zin is het right to challenge als wetgevingsinstrument niet veel anders dan een ontheffings- en/of vrijstellingsmogelijkheid voor het op een eigen manier realiseren van doelen van een wettelijke regeling (of eventueel andere publieke doelen), zonder aan de gestelde middelvoorschriften te voldoen. Bij de vormgeving is een aantal vragen te beantwoorden:

1 Wie is de doelgroep?

2 Waarvan moet kunnen worden afgeweken?

3 Wat moet de initiatiefnemer aantonen of aannemelijk maken (meestal de gelijkwaardigheid van het aangedragen alternatief ten opzichte van de geldende regels)?

4 Welke eisen moeten (eventueel) worden gesteld aan de inhoud van het voorstel?

5 Welk instrument wordt gekozen: ontheffing en/of vrijstelling?

Daarnaast kunnen eventueel nog regels worden gesteld over beoordelingscriteria, het beoordelingsproces, de openbaarheid van verleende vrijstellingen of ontheffingen, monitoring, horizonbepalingen en randvoorwaarden. ${ }^{23}$

Het right to challenge is in juridische zin dus geen zelfstandig instrument. Al naar gelang de vraag of er individueel een aanvraag ('challenge') moet kunnen worden ingediend en dus een uitzondering moet kunnen worden gemaakt, of collectief, wordt gekozen voor een ontheffing (waarover in par. 4.4.1 meer) respectievelijk een vrijstelling (waarover in par. 4.3.2 meer). Ik heb het right to challenge in paragraaf 4.3 opgenomen omdat de vrijstelling waarschijnlijk de meest gebruikte figuur zal zijn. Vanuit het gelijkheidsbeginsel zal er immers niet snel reden zijn om de uitzondering die voor de een gemaakt wordt om op een alternatieve manier de publieke doelen te bereiken, niet ook voor de ander toe te laten. Dat betekent dat een geslaagde 'challenge' dus een alternatief regime gaat bieden voor anderen die op dezelfde manier willen werken. Dan ligt het bieden van een uitzondering voor die manier van afwijken (vrijstelling) meer voor de hand dan een uitzondering voor die ene aanvrager (ontheffing). Een uitzondering hierop zal bestaan indien een bedrijf bijvoorbeeld eigen methoden hanteert om de doelen van de regelgeving te dienen die als bedrijfsgeheimen kwalificeren.

\subsubsection{Vrijstelling}

Bij de figuur van de vrijstelling zien we dat er vaak discussie is over de vraag of deze in de vorm van een algemeen verbindend voorschrift of van een concretise-

23 Zie de Handreiking Right to Challenge via www.kcwj.nl/kennisbank/integraal-afwegingskadervoor-beleid-en-regelgeving/index-beleidsinstrumenten/right-challenge. 
rend besluit van algemene strekking moet worden gegeven. Ik heb het dan over de vraag hoe de grondslag in de wet moet worden geformuleerd en, indien die formulering nog voor beide opties ruimte laat, over de wijze waarop een vrijstelling wordt vormgegeven. Deze vraag naar de vormgeving wil ik graag onderscheiden van de vraag hoe een gegeven vrijstelling juridisch wordt beoordeeld. ${ }^{24}$ In dit artikel gaat het immers met name over de vraag hoe de wetgever de verschillende instrumenten zou kunnen of moeten inzetten. We zien daarbij op dit moment verschillende vormen. Soms wordt expliciet gekozen voor het bij ministeriële regeling ${ }^{25}$ of zelfs het bij algemene maatregel van bestuur ${ }^{26}$ verlenen van vrijstellingen. De Awb kent een expliciete keuzemogelijkheid in artikel 4:64, derde lid, en artikel 4:78, vijfde lid: 'Bij wettelijk voorschrift of bij besluit van het bestuursorgaan kan vrijstelling of ontheffing worden verleend ...' Vaker wordt er niets vermeld over de vorm door een formulering als 'Onze Minister kan vrijstelling [of ontheffing] verlenen van ...'27 Uit het ontbreken van de door Ar 2.28 voorgeschreven formulering 'bij ministeriële regeling' of 'bij regeling van Onze Minister [van/ voor ...]' kan a contrario worden afgeleid dat de vrijstelling de vorm zal moeten krijgen van een concretiserend besluit van algemene strekking. ${ }^{28}$

De Ar zijn tweeslachtig op dit punt. De vrijstelling wordt in Ar 5.17, eerste lid, gedefinieerd als 'een besluit waarbij een uitzondering op een wettelijk verbod of gebod wordt gemaakt voor een categorie van gevallen'. Op zich zegt deze formulering nog niet zoveel, omdat de definitie van 'besluit' in artikel 1:3 Awb ook algemeen verbindende voorschriften omvat. Maar binnen de context van de Ar moet wel worden geconcludeerd dat geen algemeen verbindende voorschriften worden bedoeld; anders was de term 'regeling' gebruikt. Verder staat de aanwijzing in de paragraaf 'Toekenning en terminologie van bestuursbevoegdheden', los van de aanwijzingen over experimenteren die in hoofdstuk 2, 'Algemene onderwerpen van regelgeving', zijn opgenomen. Daar staat echter tegenover dat in de toelichting bij Ar 2.31 ('Afwijking bij lagere regelgeving') ${ }^{29}$ is opgenomen:

'Van de hier bedoelde gevallen dient overigens te worden onderscheiden dat wordt toegestaan dat bij lagere regeling uitzonderingen op een voorschrift in een hogere regeling worden gemaakt onder het stellen van voorwaarden of

Zie voor een overzicht van de jurisprudentie met betrekking tot die juridische beoordeling van gegeven vrijstellingen, waaruit blijkt dat de rechter zich weinig gelegen laat liggen aan de gekozen vorm: S.A.J. Munneke in: S.E. Zijlstra e.a. (red.), Wetgeven. Handboek voor de centrale en decentrale overheid (Handboeken staats- en bestuursrecht), Deventer: Kluwer 2012, p. 45-46. 
eisen en onder aanwijzing van een bepaalde groep of situatie of een tijdsperiode. Dit betreft in het bijzonder de figuur van de vrijstelling of ontheffing. Een dergelijke opzet is zeker aanvaardbaar en soms zelfs de meest voor de hand liggende.'

Dus toch een vrijstelling 'bij lagere regeling'.

Zoals uit de plaats waarop ik de vrijstelling behandel al kan worden afgeleid, pleit ik ervoor de vrijstellingsmogelijkheid te beperken tot situaties waarin de minister een bestuursinstrument moet hebben om in te spelen op ontwikkelingen die vragen om een uitzondering op de bestaande regels. De vrijstelling wordt dan dus ingezet als een concretiserend besluit van algemene strekking. De reden hiervoor is in de eerste plaats dat er rechtsbescherming moet bestaan tegen de beslissing om zo'n uitzondering te maken. Het kan niet zo zijn dat een dergelijke beslissing, die soms vergaande consequenties kan hebben omdat er rechtsongelijkheid mee wordt gecreëerd tussen degenen die onder de vrijstelling vallen en degenen met minder geluk, niet appellabel is omdat deze in de vorm van een algemeen verbindend voorschrift wordt vervat. In de tweede plaats is het ook staatsrechtelijk zuiverder. De uitzondering moet voortvloeien uit de constatering van de minister in zijn hoedanigheid van de daartoe door de formele wetgever aangewezen uitvoerder en/of handhaver van de regels (en dus als bestuursorgaan) dat voor een bepaalde groep of voor bepaalde situaties naleving van die regels niet wenselijk, onrechtvaardig of zelfs onmogelijk is. Het gaat daarbij om de toepassing van de regel waarvoor een uitzondering wordt gemaakt; de regel wordt 'uitgezet' voor een bepaalde groep of situatie, niet vervangen door een andere regel door de minister in zijn hoedanigheid van gedelegeerde regelgever. Zoals het een bestuursorgaan niet past om andersoortige regelgeving uit te proberen door middel van een experiment (zie par. 4.2.1), zo past het de gedelegeerde regelgever niet om via een vrijstelling een besluit tot inperking van de reikwijdte van een door de hogere regelgever opgestelde regel te nemen.

Keren we nog even terug bij de aangehaalde passage uit de toelichting bij Ar 2.31. Want naast het feit dat deze over het verlenen van een vrijstelling (en zelfs een ontheffing!) bij regeling spreekt, wekt deze passage om nog een andere reden verbazing. De toelichting ondergraaft namelijk de bedoeling van de aanwijzing zelf. Ar 2.31 is in 2008 geïntroduceerd ${ }^{30}$ om de mogelijkheid om bij lagere regelgeving af te wijken van hogere te beperken tot twee situaties: experimentele regelingen en noodsituaties. Maar deze passage in de toelichting zet de deur toch weer ruim open. Over de figuur van de vrijstelling is in de Ar namelijk niet meer opgenomen dan de hiervoor genoemde begripsomschrijving. Over de vraag wanneer het instrument wel en niet kan worden ingezet, zwijgen de Ar. Daarmee is de genoemde passage in de toelichting bij Ar 2.31 bijna te lezen als een aansporing om die aanwijzing te omzeilen: 'als je het nou gewoon niet hebt over het afwijken

30 In de toenmalige nummering als aanwijzing 33a, bij Regeling van de Minister-President, Minister van Algemene Zaken, van 21 augustus 2008, houdende vaststelling van de achtste wijziging van de Aanwijzingen voor de regelgeving (Stcrt. 2008, 176). Deze toevoeging diende ter uitvoering van de motie-Jurgens (Kamerstukken I 2005/06, 21109, nr. A). 
van hogere regels maar over het bij regeling geven van een vrijstelling van die regels, dan maalt niemand daarom'. Ik zie de genoemde passage in de toelichting bij Ar 2.31 dan ook graag geschrapt.

Dat brengt mij nog op een ander punt: zou de vraag wanneer de vrijstelling wel en niet kan worden ingezet niet door de Ar beantwoord moeten worden? Of zouden de Ar niet in ieder geval enige criteria moeten bevatten? Waar de inzet van de experimenteerbepaling en de hardheidsclausule (zie par. 4.4.2) in de Ar stevig aan banden is gelegd vanwege de uitzonderingen die zij mogelijk maken op algemeen verbindende voorschriften, zou ook het gebruik van de vrijstelling toch met enige waarborgen moeten zijn omkleed. Er zou op zijn minst in Ar 5.17 iets moeten staan over de noodzaak om deze zo goed mogelijk te clausuleren.

Ten slotte zou naar mijn mening de vrijstelling per definitie beperkt in tijd moeten zijn en moet de grondslag daarin voorzien. Het gaat immers om een afwijking van een regel die algemeen hoort te gelden. Dat kan gerechtvaardigd zijn om tijdelijk de benodigde 'lucht' te bieden, maar tast uiteraard het wezen van die regel aan. Indien geconstateerd wordt dat de ruimte die geboden wordt ook in de toekomst geboden moet blijven worden, is het zaak om die regel aan te passen.

Ook Zijlstra heeft kritiek op Ar 5.17, maar dan met name vanwege het ontbreken van een duidelijk onderscheid tussen de daarin beschreven instrumenten vrijstelling, ontheffing, vergunning en erkenning. Zijlstra pleit er in het boek Wetgeven voor de vrijstelling te reserveren voor reguliere, dat wil zeggen de kern van het door de wetgever beoogde reguleringsstelsel vormende, uitzondering op een gebod. ${ }^{31}$ Dat is dus anders dan Ar 5.17, waarin staat dat de vrijstelling ook voor een uitzondering op een verbod kan worden ingezet. In zijn jaarrede voor de Nederlandse Vereniging voor Wetgeving in 2018 komt Zijlstra hier echter op terug. Hij pleit er nu voor de volgende definitie in Ar 5.17 op te nemen: "Vrijstelling" wordt gebruikt voor een besluit waarbij een uitzondering op een wettelijk verbod of gebod wordt gemaakt voor een categorie van gevallen.'32 Geen beperking tot geboden dus meer en ook geen reguliere uitzondering; materieel is dit dezelfde definitie als in Ar 5.17 is opgenomen. Ik geef hem in deze laatste opvatting gelijk.

Tot slot plaats ik nog de korte opmerking dat de in de praktijk vaak in verschillende varianten gebruikte term regelluwe (of zelfs regelvrije) zone (of ruimte) in juridische zin bijna altijd een vrijstelling is. Daarom zie ik dit niet als een apart te bespreken instrument.

31 S.E. Zijlstra in: S.E. Zijlstra e.a. (red.), Wetgeven. Handboek voor de centrale en decentrale overheid (Handboeken staats- en bestuursrecht), Deventer: Kluwer 2012, p. 416.

32 S.E. Zijlstra, 'Enkele wetgevingstechnische opmerkingen over toedeling van bestuursbevoegdheid', in: S.S. Zoeteman (red.), Experimenteerwetgeving (Nederlandse Vereniging voor Wetgevingsbeleid), Tilburg: Wolf Legal Publishers 2018, p. 8. 


\subsection{Bijzondere bestuursinstrumenten}

\subsubsection{Ontheffing}

De ontheffing is volgens Ar 5.17, tweede lid, 'een beschikking waarbij in een individueel geval een uitzondering op een wettelijk verbod of gebod wordt gemaakt'. Daarmee is het bij uitstek de methode om maatwerk te bieden. Ontheffingsmogelijkheden komen, waarschijnlijk mede daardoor, veelvuldig in wetgeving voor, meestal in combinatie met vrijstellingsmogelijkheden. Het is immers een ideale mogelijkheid om de 'onvoorziene gevallen' die zich bijna per definitie bij wetgeving voordoen, een plek te geven. De kritiek die ik in paragraaf 4.3.2 uitte op het ontbreken van een inkadering van het gebruik van het vrijstellingsinstrument geldt evenzeer voor de ontheffing. Wel staat er - gek genoeg - in de toelichting bij Ar 5.25 (hardheidsclausule) wat over het gebruik van de ontheffing. Ik ga daar in paragraaf 4.4.2 nader op in. Zijlstra stelt het volgende voor over het gebruik van de ontheffing:

“'Ontheffing” wordt gebruikt voor bijzondere gevallen, waarbij kan worden gedacht aan:

a moeilijk voorzienbare of incidentele, vaak kortdurende, gevallen;

b andere niet-reguliere uitzonderingen; zo wordt een ontheffingstelsel vaak naast een vergunningstelsel gebruikt, waarbij de vergunning de gewone situatie reguleert, en de ontheffing ziet op uitzonderlijke situaties.' ${ }^{33}$

Zijlstra ziet daarbij het onderscheid tussen de vergunning en de ontheffing in het al dan niet regulier zijn van de te maken uitzondering. Ik ben dat met hem eens en bespreek om die reden de vergunning en ook de erkenning en de concessie niet in dit artikel, omdat deze niet als instrumenten voor het creëren van flexibiliteit voor maatschappelijke ontwikkelingen kunnen worden gezien.

Het pleidooi dat ik in paragraaf 4.3.2 hield voor het in tijd beperken van de vrijstelling, geldt evenzeer voor de ontheffing.

Het is, ook weer in verband met de relatie tot het right to challenge, interessant om op het Besluit experiment regelluwe scholen PO/VO in te gaan. In artikel 2 van dit besluit wordt het doel ervan met zoveel woorden vastgesteld:

'Het doel van het experiment op grond van dit besluit is te onderzoeken of het aan scholen bieden van regelluwe ruimte leidt tot initiatieven die de kwaliteit, of bij gelijkblijvende kwaliteit, de doelmatigheid van het onderwijs verbeteren en waarvoor na afloop van het experiment definitief ruimte in de WPO en WVO [de Wet op het primair onderwijs respectievelijk de Wet op het voortgezet onderwijs; DdK] gecreëerd kan worden.' 
Om dit te bereiken kan de Minister van Onderwijs, Cultuur en Wetenschap (OCW) aan scholen waarvan het onderwijs 'aantoonbaar een goede kwaliteit heeft', en indien de medezeggenschapsraad ermee instemt (art. 3), het predicaat 'regelluwe school' geven. De beoordeling van de 'goede kwaliteit' heeft voordien al plaatsgevonden door een jury die een lijst heeft aangelegd met 'excellente scholen'. ${ }^{34}$ Het bevoegd gezag van een regelluwe school kan vervolgens besluiten van een groot deel van de onderwijswetgeving af te wijken na een simpele melding daarvan aan de Minister van OCW (art. 5). De minister kan alleen achteraf ingrijpen (art. 7). Evenals de in paragraaf 4.2.2 besproken Experimentenwet gemeenten heeft dit besluit een hybride karakter. Er is sprake van een experiment, omdat het doel blijkens artikel 2 is te kijken of er ruimte moet worden gecreëerd in de WPO en de WVO en er daartoe ook een onderzoek wordt verricht (art. 9). Daarnaast bevat het besluit kenmerken van het right to challenge, in die zin dat een school zelf kan beslissen dat zij op een andere manier voor goed onderwijs kan zorgen dan door het volgen van de daartoe gestelde regels. Het verschil met het right to challenge is echter dat er geen aanvraag wordt ingediend voor de afwijking(en), maar dat de mogelijkheid voor die afwijking is gegeven door de individuele kwalificatie als 'excellente school' en daarmee als regelluwe school. In feite ligt daar dus de inhoudelijke beoordeling: die scholen hebben met die aanwijzing een ontheffing ontvangen van de desbetreffende bepalingen. Daarom deel ik dit besluit in onder de ontheffing. Over dit besluit heeft Florijn in een eerder nummer van RegelMaat een kritische beschouwing geschreven. ${ }^{35}$

\subsubsection{Hardheidsclausule}

De formulering van Ar 5.25, eerste lid (voorheen Ar 131, eerste lid), heb ik altijd een wonderlijke gevonden:

'In een regeling wordt geen hardheidsclausule opgenomen, tenzij er aanleiding is om te verwachten dat, gelet op het doel en de strekking van de regeling, de toepassing van de regeling kan leiden tot onbillijkheden van overwegende aard in niet precies te voorziene gevallen of groepen van gevallen.'

Wat een hardheidsclausule is, moeten we maar afleiden uit hetgeen volgt op 'tenzij': het moet blijkbaar gaan om een clausule om 'onbillijkheden van overwegende aard in niet precies te voorziene gevallen of groepen van gevallen' te kunnen aanpakken. En daarmee staat er dus eigenlijk in deze aanwijzing: 'neem geen hardheidsclausule op tenzij er reden is om een hardheidsclausule op te nemen'. Een weinig richtinggevende aanwijzing dus. Uit deze formulering en de toelichting bij deze aanwijzing blijkt wel hoe kritisch de Ar zijn over het gebruik van dit instrument. Het primaat van de wetgever en de conflictopwekkendheid van een dergelijke clausule worden als argumenten hiervoor genoemd. Ondanks deze roep om terughoudendheid komt een hardheidsclausule, die door zijn bijzondere for-

35 E. Florijn, 'Paden naar Utopia. Over regels, regeldruk en experimenten in het onderwijs', RegelMaat 2016 afl. 2, p. 117-127. 
mulering met de 'onbillijkheden van overwegende aard' in wetten.nl gemakkelijk te traceren is, nog in 99 regelingen voor.

Op de verhouding van dit instrument tot de ontheffing en vrijstelling gaat de toelichting bij Ar 5.25 in:

'Een hardheidsclausule onderscheidt zich van ontheffings- en vrijstellingsbepalingen, doordat vooraf niet (precies) te voorzien is of afwijking nodig zal zijn en zo ja, om welke gevallen of groepen gevallen het bij de toepassing zal gaan. Voorts beperkt de toepassing van een hardheidsclausule zich tot (eventuele) onbillijkheden van overwegende aard. Bij ontheffingen is het juist van meet af aan de uitdrukkelijke bedoeling om in bepaalde, individuele, voorzienbare gevallen een uitzondering te maken op de wettelijke regel. Alleen wanneer een ontheffings- of vrijstellingssysteem zeer gebonden bevoegdheden bevat, kan voor het daarnaast opnemen van een hardheidsclausule nog ruimte zijn.'

Ik vind dit een rare redenering. De Ar definiëren de ontheffing als 'een beschikking waarbij in een individueel geval een uitzondering op een wettelijk verbod of gebod wordt gemaakt', zo zagen we al. En dat is een hardheidsclausule toch ook? Waar die uitzondering voor mogelijk wordt gemaakt, wordt door Ar 5.17, tweede lid, in het midden gelaten. Dat kunnen ook gevallen zijn waarin anders 'onbillijkheden van overwegende aard' zouden ontstaan. Daarom zie ik de hardheidsclausule als een vorm van een ontheffing. Net zoals het right to challenge een vorm van een ontheffing is voor individuele gevallen waarin 'het doel op een andere manier kan worden bereikt'. Maar ook de bewering in de aangehaalde passage, dat de ontheffing zich zou (moeten?) beperken tot voorzienbare gevallen, waag ik te betwijfelen. Is de ontheffing niet juist (ook) bedoeld voor onvoorzienbare gevallen? Dat is ook wat Zijlstra bepleit, zo zagen we eerder. Wellicht is de gedachte dat bij een ontheffing een clausule wordt opgenomen waarin duidelijk wordt gemaakt wat voor soort gevallen in aanmerking komen voor een ontheffing. Maar dat is dan wel afhankelijk van het bestaan van zo'n clausule. Soms is die er überhaupt niet, ${ }^{36}$ soms heeft die juist expliciet betrekking op "bijzondere gevallen' ${ }^{37}$ Kortom: ik zie niet waarom de hardheidsclausule als apart instrument moet worden behandeld en niet gewoon als species van de ontheffing (die het in mijn ogen is) in Ar 5.17. Als daarin iets wordt opgenomen over de clausulering van de ontheffing, zoals ik al bepleitte, kan de hardheidsclausule mooi als voorbeeld worden genoemd.

36 Bijv. art. 38, tweede lid, Meststoffenwet ('Onze Minister kan ontheffing verlenen van het bij of krachtens deze wet bepaalde'), art. 1:33, tweede lid, Algemene douanewet ('Onze Minister van Financiën kan, op verzoek, ontheffing verlenen van de in het eerste lid omschreven verplichting') en art. 4:64, derde lid, Awb ('Bij wettelijk voorschrift of bij besluit van het bestuursorgaan kan vrijstelling of ontheffing worden verleend van het in het tweede lid bepaalde').

37 Bijv. art. 12, derde lid, Advocatenwet ('om bijzondere redenen') en art. 4, vierde lid, Drank- en horecawet ('met het oog op bijzondere gelegenheden van zeer tijdelijke aard'). 
De hardheidsclausule heeft recent weer extra aandacht gekregen als gevolg van het rapport van de Wetenschappelijke Raad voor het Regeringsbeleid 'Weten is nog geen doen. Een realistisch perspectief op redzaamheid'. Vanwege het daarin vervatte pleidooi om van overheidswege meer rekening te houden met het 'doenvermogen' van de burger, pleitte Scheltema in RegelMaat voor het opnemen van het volgende algemene artikel in de Awb:

\section{'Artikel 3:4a}

Indien de toepassing van een wettelijke regel leidt tot nadelige gevolgen die onevenredig zijn in verhouding tot de met die regel te dienen doelen, en de belanghebbende hiervan geen verwijt kan worden gemaakt, kan van de regel worden afgeweken voor zover dat nodig is om tot een meer evenwichtige regeltoepassing te komen. ${ }^{\text {,3 }}$

Hoewel Scheltema de bewoording van de modelbepaling voor de hardheidsclausule van Ar 5.26, tweede lid, niet gebruikte, is de aard van de voorgestelde bepaling wel degelijk die van een hardheidsclausule. Hij heeft zich daarbij weinig aangetrokken van de bezwaren tegen het gebruik van dit instrument die in de Ar worden opgevoerd, en die zich hier vanwege de zeer algemene aard van de voorgestelde bepaling ('een wettelijke regel') duidelijk doen gelden. Mij lijkt deze bepaling wel erg ver gaan en het bezwaar van conflictopwekkendheid zie ik hier levensgroot voor me: hoe vaak zal niet een beroep worden gedaan op deze bepaling voor de toepassing van allerlei bijzondere wetgeving?

\section{Conclusie en aanbevelingen}

De ruimtegevende instrumenten kunnen op grond van het voorgaande schematisch worden ingedeeld als weergegeven in figuur 1 .

Naar mijn mening moet linksboven worden begonnen met de afweging: kunnen we de regelgeving zodanig opstellen dat deze de - ook door de Raad van State bepleite - flexibiliteit inherent bezit? In dat geval hebben we immers geen instrumenten meer nodig om dat op ad-hocbasis te moeten doen. Mocht een dergelijke formulering niet mogelijk of wenselijk zijn, dan komt de vraag op of we de regelgever of het bestuursorgaan de 'ontsnappingsmogelijkheid' willen geven. Is het een zaak van andere/nadere regels en blijven we dus aan de linkerkant van het schema, of van bestuursbesluiten tot uitzonderingen en slaan we dus rechtsaf? In het laatste geval is het nog de vraag of we categoraal of individueel willen kunnen afwijken en dus boven of onder terechtkomen. Het right to challenge en de hardheidsclausule heb ik tussen haken opgenomen, omdat ze in mijn ogen niet als bestuursrecht. Een pleidooi voor enige vrijzinnigheid maar vooral voor Einzelfallgerechtigkeit', NTB 2019, afl. 7, p. 280 e.v. 


\section{Figuur 1 Schematische indeling van ruimtegevende instrumenten}

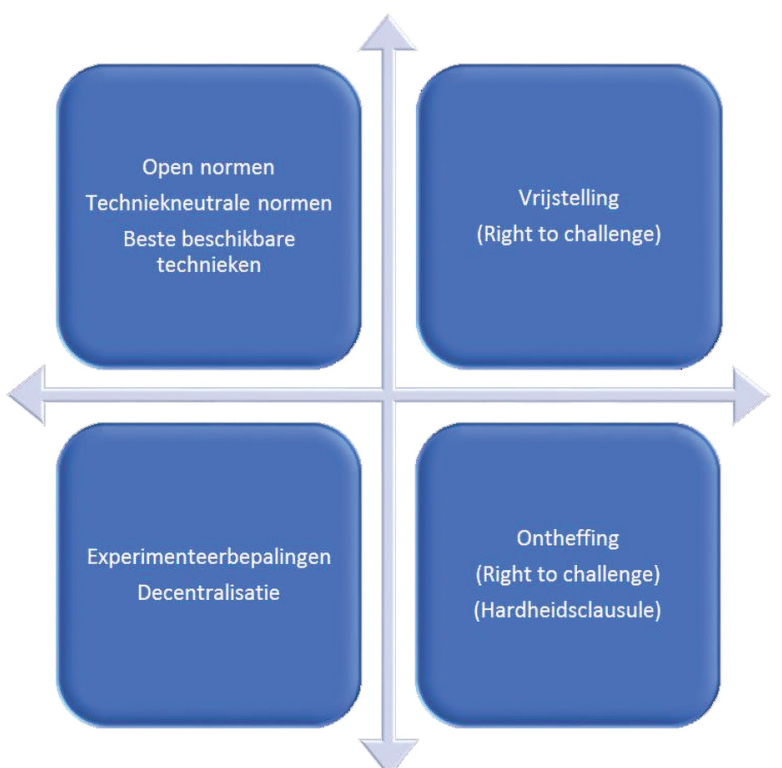

separate instrumenten maar als bijzondere vormen van de vrijstelling en/of de ontheffing moeten worden gezien.

Daarnaast heb ik in paragraaf 4 (veelal uitdrukkelijk, maar soms wat impliciet) een aantal aanbevelingen gedaan voor aanpassing van de Ar. Voor het overzicht herhaal ik deze aanbevelingen hier verkort, of werk ik ze nog wat uit, in de volgorde van de Ar. Verder heb ik nog een aanvullende aanbeveling met betrekking tot het right to challenge:

1 Schrap de passage in de toelichting bij Ar 2.31 over de aanvaardbaarheid van het gebruik van de ontheffing of vrijstelling om te kunnen afwijken van hogere regelgeving.

2 Maak duidelijk dat het vrijstellings-, ontheffings- en vergunningsinstrument niet bedoeld is voor experimenteren met regelgeving. Daarvoor dient de experimenteerbepaling van Ar 2.41 te worden ingezet.

3 Geef in Ar 5.17 duidelijk aan dat de vrijstelling bedoeld is als bestuursinstrument en dus moet leiden tot de bevoegdheid van een bestuursorgaan om een concretiserend besluit van algemene strekking te nemen.

4 Neem in Ar 5.17 op dat de vrijstelling en de ontheffing bedoeld zijn als tijdelijke instrumenten.

5 In navolging van Zijlstra: expliciteer in Ar 5.17 dat de ontheffing bedoeld is voor onvoorzienbare gevallen, waar de vergunning bedoeld is voor voorzienbare gevallen.

6 Schrap de specifieke aanwijzing over de hardheidsclausule en neem in Ar 5.17 bij de ontheffing op dat de hardheidsclausule een van de mogelijke vormen is. 
D.R.P. de Kok

7 Neem in Ar 5.17 bij de vrijstelling en de ontheffing op dat het right to challenge een van de mogelijke vormen is. 